\title{
A snapshot of the coaching practices in undergraduate nursing education: evaluation of stakeholders' perceptions and program costs
}

\section{Hemşirelik lisans eğitiminde koçluk uygulamalarının bir görüntüsü: Paydaşların algılarının ve program maliyetlerinin değerlendirilmesi}

https://doi.org/10.1515/tjb-2019-0154

Received July 2, 2019; accepted January 2, 2020;

published online August 20, 2021

\section{Abstract}

Objectives: Skills training is carried out with coaching in nursing education and all stakeholders are important. The aim of study was to evaluate the views of different stakeholders on coaching practice and the costs.

Methods: Data was collected between October 2015 and December 2016. The student dimension was evaluated using the Coaching Process Evaluation Scale with sophomore $(n=237)$ and junior $(n=219)$. Data was collected from the faculty member $(n=18)$ using Critical Incidents Technique and from the educational managers $(n=7)$ through in-depth interviews. The 2015-2016 educational program was analyzed for cost analysis.

Results: Student evaluations of the Coaching Process Evaluation Scale demonstrated mean scores of $66.68 \pm 0.85$ for the Observed Coaching Skills subscale. There were four headlines (use of coaching skills, benefiting from the

*Corresponding author: Hatice Şahin, Medical Doctor, Department of Medical Education, Ege University Faculty of Medicine, Izmir, Bornova, Turkey, E-mail: hatice.sahin8@gmail.com. https://orcid.org/00000002-5200-7533

Hale Sezer, Nursing Education Department, Izmir Bakırçay University Faculty of Health Science, Izmir, Turkey. https://orcid.org/00000003-4199-7727
Coaching Process, Emotions, and Reflection) which were also observed in the faculty members data which revealed a total of 60 codes from positive and negative incidents. The educational managers, on the other hand, stressed three categories and the emotions category, which emerged in the students and faculty was not found among the educational managers. The per student cost of practice education increase sixfold from the freshman year to the junior year.

Conclusions: The perception and views on coaching practices of educational managers, faculty members, and students are positive and support each other. This provides an important opportunity for the placement of coaching practices into education programs in nursing.

Keywords: coaching; cost of educational program; nursing education.

Öz

Amaç: $\mathrm{Bu}$ çalışmada, hemşirelik eğitiminde koçluk modelinin geliştirilmesi için farklı tarafların görüşlerinin değerlendirilmesi ve koçluk uygulamalarının maliyetinin ortaya konulması amaçlanmıştır.

Yöntem: Araştırmanın verileri Ekim 2015-Aralık 2016 tarihlerinde arasında toplanmıştır. Öğrenci boyutu, 2. Sınıf ( $n=237)$ ve 3. sınıf ( $n=219)$ öğrencilerinden Koçluk Süreci Değerlendirme Ölçeği kullanılarak değerlendirilmiştir. Öğretim elemanlarından veriler $(\mathrm{n}=18)$ Kritik Olaylar Tekniği ve Eğitim yöneticilerinden $(n=7)$ derinlemesine görüşme formu ile toplanmıştır. Fakültenin 2015-2016 
eğitim programı, program maliyeti açısından analiz edilmiștir.

Bulgular: Öğrencilerin Koçluk Süreci Değerlendirme Ölçeğine göre; Gözlenen Koçluk Becerileri alt ölçeğinden ortalama $66.68 \pm 0.85$ değer bulunmuştur. Öğretim elemanlarından elde edilen olumlu ve olumsuz olaylardan toplam 60 kodda 4 kategori (koçluk stratejilerinin kullanımı, yararlanım, duygular ve refleksiyon) saptanmıştır. Eğitim yöneticileri derinlemesine görüşmelerde üç kategoriyi vurgulamış, öğrencilerde ve öğretim elemanlarında ortaya çıan duygular kategorisi eğitim yöneticilerinde saptanmamıştır. Uygulamalı eğitimlerde öğrenci başına düşen maliyet birinci sınıftan üçüncü sınıfa kadar 6 kat artmaktadır.

Sonuç: Eğitim yöneticileri, öğretim elemanları ve öğrencilerin koçluk uygulamalarına ilişkin algı ve görüşleri olumludur ve birbirlerini desteklemektedir. Bu, koçluk uygulamalarının hemşirelik eğitim programlarına yerleştirilmesi için önemli bir fırsat sağlamaktadır.

Anahtar Kelime: Hemşirelik Eğitimi; koçluk; program maliyeti.

\section{Introduction}

In nursing education, which includes theoretical and practical aspects, the aim is to train students so that they use their full potential. The cultural and professional skills and knowledge within the context of nursing education are further shaped through the system of values held by the students [1]. The coaching practice of professional nursing education is an active process [1,2] which uses educational coaching to raise awareness in the individual of his/her own resources and improve his/her own performance.

Learning and development are the main focus points in coaching. To help the learning and development of a person receiving coaching, the person should be made aware of his/her stronger aspects and resources. Educational coaching is defined as raising personal awareness on the stronger aspects and resources of a recipient and encouraging learning and development through focusing on the future and solutions $[3,4]$. The role of coaches on nurses, realizing the theoretical and applied information received during education, in their work life is important [5]. Coaching has an important role not only in the provision of professional skill but also in the acquisition of critical thinking skills and following contemporary knowledge [6].

Most of the studies in the literature are focused on the business management discipline and upper management coaching [7-9]. A large majority of the academic studies on educational coaching can be seen to be focused on the students, dealing with student learning. Coaching studies on professional development in education or leadership improvement, on the other hand, have long been limited to colleague coaching practice [10-12].

Many coaching models that could be used in nursing and nursing education were developed. In these models, the focus was on the coaching practice and variables other than the faculty members and the student were excluded from the process.

The aim of this study was to evaluate the views of different stakeholders (students, faculty members, and management) on the development of coaching models and to exhibit the costs of coaching practices.

\section{Materials and methods}

Data for this mixed method study was collected between October 2015 and December 2016. Since data was collected from students, faculty members, and educational managers through different techniques and in different time intervals, sampling, data collection tools, and the analysis also differed.

a. Data regarding the students consisted of sophomore and junior year students studying at the Nursing Faculty. The sample size of the study was calculated using the formula " $n=N$ t2pq/d2 $(\mathrm{N}-1)+\mathrm{t} 2 \mathrm{pq}$ ". Accordingly, the target numbers of 237 sophomores $(n=480)$ and 219 juniors $(n=396)$ were reached. Data was collected from the sophomores and juniors on different sessions. To determine the views of the students on coaching in skills training, the Coaching Process Evaluation Scale (CPES) was used [13]. The CPES consists of 30 items and four subscales. The subscales are Observed Coaching Skills (11 items), Emotions (4 items), Benefiting from the Coaching Process (12 items) and Expected Coaching Skills (3 items). The scale is scored through Likert type scoring (1-5). The total scores of the subscales are calculated instead of the total score from the scale. The numbers of items in the subscales were not equal. However, the scores have standardized so that the subscales can be compared to each other. The scores of the subscales can vary between 0 and 100 . As the scores reach 100 , the satisfaction of the students with regard to the items in the subscales increase. Data obtained from the students was analyzed using the SPSS 25 package program and distribution statistics (frequencies, percentages, mean values, standard deviation) were calculated.

b. Data regarding the faculty members consisted of faculty members providing skills training to sophomores and juniors $(n=18)$. All of the faculty members were included in the study. Data was collected from the faculty members using the Critical Incidents Technique (CIT). In this technique, the faculty members were asked through the prepared form to describe three positive and three negative memories regarding coaching practice in skills training in a detailed manner. The CIT forms handed out to the faculty members to answer. The faculty members were reminded to fill the forms three times, ensuring that they wrote down not 
general views but "memories". Expected critical incidents number from faculty members were 106. Accordingly, the expected number of incidents would be sufficient with regard to data reliability [14]. The incidents analyzed in three sessions by a team consisting of the researchers, two students not included in the study, and one faculty member not included in the study. In data analysis, the incidents were read and codes, categories, and subthemes were determined through consensus. In the determination of the categories and subthemes from the codes, the item captions of the CPES were taken into consideration. Sample sentences from the categories were also chosen to present in the findings.

c. Data regarding the educational managers consisted of the managers of the Nursing Faculty ( $n=7$ ), but only five of the managers could be reached. The views of the educational managers on coaching in skills training were obtained through in-depth interviews. The interviews were performed using a form including questions regarding the place of coaching in skills training. For the in-depth interviews, the managers with whom appointments were made were interviewed one on one with voice recording over a duration of 15 days. The verbal data obtained from the interviews were turned into transcripts, and codes, categories, and sub themes were determined through analysis. Sample sentences from the categories were also chosen to present in the findings.

d. The total course hours, skills training hours, the distribution of skills training hours according to years of study, the number of faculty members providing coaching according to years of study, the personnel costs per student in skills training (faculty member and helping staff), and the total cost per student for skills training in the 2015-2016 educational program applied by the Nursing Faculty were analyzed.

Ethical Board permission was taken for the study (dated 01/10/2015 and numbered/27344949/508-2911). Verbal consent from the students and written consent from the faculty members and educational managers were also obtained for the study.

\section{Results}

The findings of the study will be presented in four separate groups, namely the views of the students, the views of the faculty members, the views of the educational managers, and educational program analysis.

a. The views of the students

A total of 456 nursing students participated in the study. $52 \%(n=237)$ of these were sophomores while $48 \%(n=219)$ were juniors. $80.3 \%$ of the students were in the $18-21$ age interval and $86 \%$ were female. According to the Coaching Process Evaluation Scale, mean subscale scores were calculated (Graph 1).

b. The views of the faculty members

The total number of critical incidents collected from the 18 faculty members providing coaching in skills training was 85 , where 42 were positive and 43 were negative. 27 codes

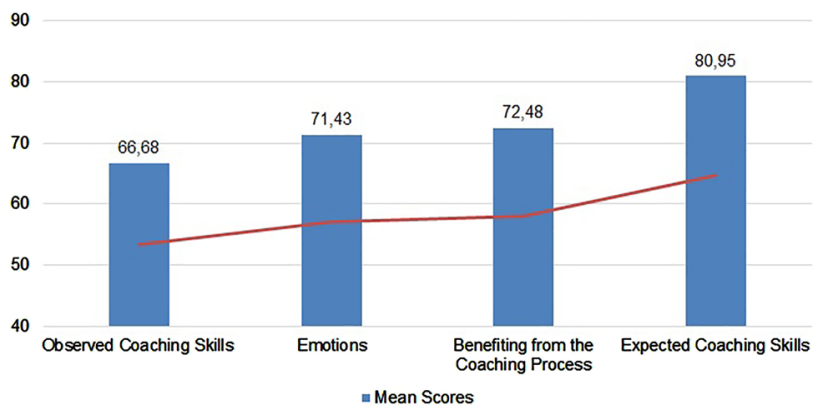

Graph 1: The subscale mean scores of the coaching process evaluation scale.

from the positive incidents and 33 codes from the negative incidents were determined. These 60 codes were categorized under four headlines (use of coaching strategies, benefiting from the Coaching Process, Emotions, and Reflection) for both positive and negative incidents.

In the use of Coaching strategies category, content that complied with the observed coaching skills subscale of the CPES applied to the students was found. Sample statements of positive and negative incidents pertaining to this category were given below.

“... I noticed that one of the students turned her back and plugged
her ears since she was disturbed by the sound of aspiration. When I
talked to the student, she said that aspiration made her nauseous.
... I talked to my student and explained why this procedure needed
to be performed. Without pushing her much, I integrated her into
aspiration in time...” (Faculty Member 1).

"After my student drew blood from a patient, she punctured herself with the needle by touching the back of the vacutainer. I felt guilty for not telling about that part.... However, after that, I insistently stressed that the vacutainer needle could puncture one's hand to all of the new groups.” (Faculty Member 15).

In the Benefiting from the Coaching Process category, content that complied with the benefiting from coaching skills subscales of the CPES applied to the students was found. Sample statements of positive and negative incidents pertaining to this category were given below.

"Our highly anxious patient adopting a cute attitude instead of prejudice after our student made explanations during IV drug administration and correctly applied all the steps of the procedure.” (Faculty Member 14).

“... a patient who was undergoing enteral feeding had pill treatments. With my student, we crushed the pills, watered them down, and drew the mixture into an injector, and when we went to the bedside of the patient and I asked where we could apply this treatment to the student before the skills training, she answered intravenously. This showed that we did something wrong somewhere." (Faculty Member 1). 
In the Emotions category, content that complied with the emotions subscales of the CPES applied to the students was found. Sample statements of positive and negative incidents pertaining to this category were given below.

“... an inpatient under (emergency) monitoring needed to be applied a urinary catheter... they asked us. My student first got very excited. Then she got worried about whether she could do it. I told her that she could, that I would be there, and that I would intervene if necessary." (Faculty Member 9).

"I was very happy when my students who applied IV interventions for the first time were happy after the skills training, thanking me for my help." (Faculty Member 10).

In the Reflection category, content that complied with the expected coaching skills subscale of the CPES applied to the students was found. Sample statements of positive and negative incidents pertaining to this category were given below.

"When one of my professors noticed that the students couldn't perform an intravenous pathway, my professor intervened but couldn't succeed. This, happening in front of the students, was awkward to handle. Then, my professor asked me to do it. I was able to perform a pathway without difficulty. The dilemma I experienced at that point disturbed me. The patient experiencing pain multiple times, the point of view of the students, and the confusion about whether to intervene or not thinking "what would my professor think" made me feel uncomfortable." (Faculty Member 16).

"I had a student to whom I thought I gave a lower mark than deserved while evaluating care plans prepared by the students. When I remember this, I get sad.” (Faculty Member 18).

c. The views of the educational managers

The mean duration of employment as academicians was $27 \pm 9.6$ ( $\min 16-\max 35)$ years. The managers served in management for a mean duration of $2.33 \pm 1.1$ years. They stated that they served as faculty members in skills training for a mean duration of $27.2 \pm 9.3$ years. In the in-depth interviews, the educational managers stressed three categories, namely the characteristics of the coach, benefiting, and coaching practice.

The characteristics of the coach category was found to include content in compliance with the Observed Coaching Skills subscales of the CPES and the use of coaching strategies category determined through the CIT applied to the faculty members. Sample statements pertaining to this category were given below. “...first and foremost (the coach) should be a role model to the students regarding dressing and behavior, communication, relations to each other, relations to the team member, and relations to the patient..." (Faculty Member 4)

“... should be patient and tolerant with regard to personal characteristics. The coach should also be motivating, giving feedback not only from a critical point of view but from a positive one. The coaches should not get bored and like their job and themselves. They should be able to become a role model. Of course, they should also have a base of knowledge on the job. They should be tested with regard to their skill and experience." (Faculty Member 3)

The benefiting category was found to include content in compliance with the Benefiting From Coaching Skills subscales of the CPES and the benefiting category determined through the CIT applied to the faculty. Sample statements pertaining to this category were given below.

“...(coaching practice) increase motivation and satisfaction...” (Faculty Member 1)

“...would be a more systematical approach...”(Faculty Member 2)

“...I also think that coaching would be beneficial practically in managing the workforce and time better...” (Faculty Member 3)

“...If there was something left unexplained in our program, it would be integrated... better equipped students of higher quality would be raised." (Faculty Member 5)

The data from educational managers, faculty members, and students supported each other (Table 1). The emotions category, which emerged in the students and faculty member was not found among the educational managers. This shows that educational managers did not take the power of coaching practice to affect the emotions of students and faculty members positively or negatively into consideration.

Table 1: The integration of the data from educational managers, faculty, and students.

\begin{tabular}{lll}
\hline Students' data & Faculties' data & $\begin{array}{l}\text { Educational } \\
\text { managers' data }\end{array}$ \\
\hline $\begin{array}{l}\text { Subscale } \\
\text { Observed coaching skills }\end{array}$ & $\begin{array}{l}\text { CIT categories } \\
\text { Use of coaching } \\
\text { strategies }\end{array}$ & $\begin{array}{l}\text { In depth interview } \\
\text { Coach characteristics }\end{array}$ \\
$\begin{array}{ll}\text { Emotions } \\
\text { Benefiting from the } \\
\text { coaching process } \\
\text { Expected coaching skills }\end{array}$ & $\begin{array}{l}\text { Reflection } \\
\text { Benefiting }\end{array}$ & Benefiting \\
\hline
\end{tabular}


The findings regarding the per student cost and duration of the courses requiring coaching practice within the education program were given below.

d. Analysis of the educational program

Undergraduate nursing education is four-years and the total course hours is 4,272. Among these, $2,144 \mathrm{~h}$ were allocated to skills training performed with a coach. The number of students attending courses that require coaching practice at the Ege University Faculty of Nursing is 1,145 while the number of faculty member is 126 (14 professors, 18 assistant professors, 18 faculty member with $\mathrm{PhD}$, three faculty member, 73 research assistants) The per student cost in courses with coaching practice vary according to years of study. The number of skills training hours and training costs increase parallel to years of study. The per student cost of skills training increase sixfold from the year to year. Thus, per student cost is an important criterion in skills training. The per student cost consists of two basic components, namely material costs and staff (faculty member) costs. Although per student material costs do not change according to years $(67.49 \mathrm{TL})$, the staff costs per student increase each year. Staff costs can be seen to hold a big place among total costs (between 80.07 and 96.69\%). This situation also shows the necessity of coaching training. The increasing number of applied courses over the years and the necessity to teach more lecturers without changing the duration of practice per student in these courses are the reason of increasing the cost of teaching staff (Table 2, Graph 2).

\section{Discussion}

The aim of this study was to evaluate the views of different stakeholders (students, faculty members, and management) on the development of coaching models and to exhibit the costs of coaching practice.

Our findings showed that the views of students, faculty members, and educational managers on coaching practice in the education program supported each other.

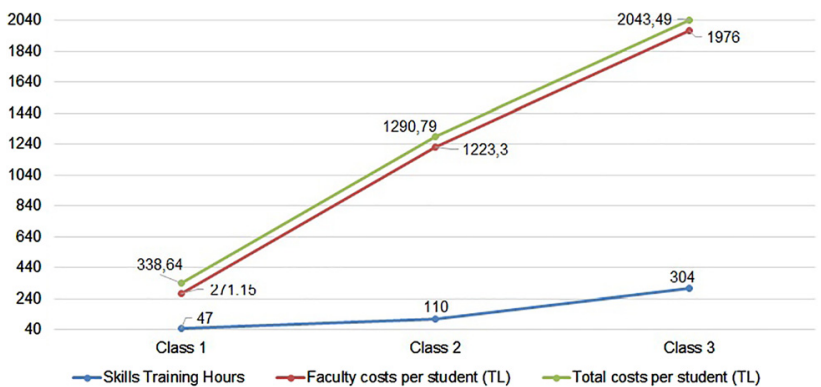

Graph 2: Skills training cost analysis per student.

When the CPES findings of the sophomore and junior students participating in our study were examined, the expectations of the students regarding coaching skills were found to be high, the students were found to benefit from the coaching process, and the emotions of the students on the subject were found to be positive in a manner parallel to this benefit. Despite this positivity, the students stated their observed coaching skills parameter, which means the coaching skills they encountered in practical courses, to be less satisfying. The topics of the coach being self-aware and open to improvement, the coach being able to selfevaluate, and the holistic evaluation of the educational program are all included by the Expected Coaching Skills subscales. The Expected Coaching Skills subscales mean scores from the CPES can be interpreted as the students expecting their faculty members to improve their coaching skills. Our study and related studies show the satisfaction and expectations of the students with the coaching practice in a similar manner. The presence of qualified faculty members in nursing faculties is a problematic issue $[15,16]$. Faculty members need to receive continuous professional development to contribute to their knowledge and experiences [17]. Continuous professional development is a process that includes skills training evaluation, the definition of learning needs, participation in learning processes, and the reflection of the results of the aforementioned actions [18]. Reflective processes are realized in professional improvement activities through activities such as coaching, mentoring, or clinical observation [19, 20]. In order to

Table 2: Faculty costs per student.

\begin{tabular}{rrrrrrrr}
\hline Year & $\begin{array}{r}\text { Skills training } \\
\text { hours }\end{array}$ & $\begin{array}{r}\text { No of } \\
\text { faculty }\end{array}$ & $\begin{array}{r}\text { No of } \\
\text { students }\end{array}$ & $\begin{array}{r}\text { Faculty costs per } \\
\text { student (TL) }\end{array}$ & $\begin{array}{r}\text { Material costs per } \\
\text { student (TL) }\end{array}$ & $\begin{array}{r}\text { Total cost per } \\
\text { student }\end{array}$ & $\begin{array}{r}\text { Ratio of faculty costs to } \\
\text { total cost, \% }\end{array}$ \\
\hline 1 & 47 & 11 & 286 & 271.15 & 67.49 & 338.64 & 80.07 \\
2 & 110 & 25 & 281 & 1223.3 & 67.49 & 1290.79 & 94.77 \\
3 & 304 & 36 & 396 & 1976 & 67.49 & 2043.49 & 96.70 \\
\hline
\end{tabular}


improve the reflective thinking habit of the faculty members in nursing skills training, faculty members need to be educated on the underlying cognitive dimension [21].

The faculty members stressed that the coaching practice in the education program were beneficial and well executed and positively affected their emotions and those of the students. In order to be able to train their students as professionals who can think critically, solve problems, participate in teamwork, and transfer information faculty members need to be educated. Coaching can be used in the provision of professional development [22-26]. The reasoning behind coaching is defined as developing understanding through discussion and reflective thinking [27]. Coaching is also related to the competencies to face challenges more effectively and improve self-efficacy [28]. In a study performed with nurse managers, coaching was found to benefit manager nurses when they undertook a complicated, pressuring, and vulnerable role [27]. The fact that coaching contributes not only to students but also to faculty member was exhibited through these studies in manner similar to ours.

In our study, educational managers discussed the necessary coaching characteristics that people involved in coaching practice should possess and the benefit of the coaching practice for the students and the institution. Educational managers stressing the benefit of coaching practice and the importance of the characteristics of the coach in increasing this benefit is an important finding regarding the realization of coaching process. Managers' believing in the benefit of coaching practice is an important opportunity for the placement of coaching practice into the education program and the encouragement of faculty members to receive coaching training. In similar studies, faculty development programs were seen to be organized by managers so that faculty members who recently entered the profession could show effective activity in the fields of teaching, research, and health services $[29,30]$.

In our study, the per student cost and duration of courses which require coaching practice in the educational program were found to be significant. It was seen that staff costs were higher among the costs and that the duration per student was applied in a manner increasing with years of study. As the yearly per student program cost was calculated in the Houston University Health Sciences Center, the wages of the faculty were stated to have an important place within those costs [31]. In a model formed to determine education costs, teaching costs (the cost of activities directly related to teaching), education costs (teaching costs plus general supervisor costs), and Milieu costs (education costs plus research costs) were taken into consideration [31, 32]. With this model, the teaching and education costs tied to faculty members were found to form half of the general cost of education in a manner that supports our findings. According to HUCEP and European Union standards, clinical education in nursing education programs should form at least half of the total education $[33,34]$. The weight of the applied courses that require coaching within the educational program of the Nursing Faculty members can be seen to meet standards approximately. When cost loads are taken into consideration in education programs, a risk of decreasing practical course hours emerges. In order to better management of staff costs, which is the main field of cost reduction, qualified faculty members are necessary. For qualified faculty to exist, teaching education and the monitoring of faculty members are elementary. Thus, effective skills training can be possible without increasing costs further or decreasing skills training hours.

Similarly, it has been stressed in literature that education management should develop a financial and budgetary approach [29]. The issue of educational costs is important not only with regard to skills training but also with regard to different reasons such as educational accreditation.

\section{Conclusion}

The students receiving coaching, the faculty members providing coaching, and managers who are in the decision-making mechanism for the execution of coaching model are important stakeholders in education. Our study reveals that all these stakeholders have positive views on coaching practice that support each other and we propose that this is an important opportunity for the placement of coaching practice into education programs and the realization of the training of the faculty member who would take place in those skills training. The conversion of this opportunity into a positive education environment is only possible though educational management applying faculty development programs by also taking costs into consideration. Institutions should have special faculty development programs specific to education programs. The evaluation of the presence and effectiveness of faculty development program in the accreditation of an education program makes these efforts even more noticeable. In future studies, the relationship between the effectiveness of the courses that require coaching practice within accredited programs and the effectiveness of faculty development programs should be evaluated. 
Research funding: None declared.

Author contributions: All authors have accepted responsibility for the entire content of this manuscript and approved its submission.

Competing interests: Authors state no conflict of interest. Informed consent: Informed consent was obtained from all individuals included in this study.

Ethical approval: Ethical Board permission was taken for the study (dated 01/10/2015 and numbered/27344949/508-2911).

\section{References}

1. Ajani K, Moez S. Gap between knowledge and practice in nursing. Proc Social Behav Sci 2011;15:3927-31.

2. Maginnis C, Croxon L, Croxon C. Transfer of learning to the nursing clinical practice setting. Rural Rem Health 2010;10:1313-20.

3. Hayes E, Kalmakis KA. From the sidelines : coaching as a nurse practitioner strategy for improving health outcomes. Am Acad Nurse Pract 2008;19:555-62.

4. Donner G, Wheeler MM. Coaching in nursing: an introduction. Indianapolis: International Council of Nurses and The Honor Society of Nursing; 2009. http://www.donnerwheeler.com/ documents/STTICoaching.pdf [Accessed 12 Aug 2021].

5. Oermann MH, Muckler VC, Morgan B. Framework for teaching psychomotor and procedural skills in nursing. J Cont Educ Nurs 2016;47:278-82.

6. Lauire G. The skills of coach are an essential element in clinical learning. J Nurs Educ 2000;39:231-3.

7. Dembkowski S, Eldridge F, Hunter I. Seven steps of effective executive coaching. London: Thorogood Publishing; 2006.

8. Linder-pelz S. Steps towards the benchmarking of coaches' skills. Int J Evid Based Coach Mentor 2014;12:47-62.

9. Passmore J, Brown A. Coaching non-adult students for enhanced examination performance: a longitudinal study. Coach Int J Theory Pract Res 2009;2:54-64.

10. DeBourgh GA. Psychomotor skills acquisition of novice learners. Nurse Educ 2011;36:144-9.

11. Showers B. Teachers coaching teachers. Educ Leadersh 1985; 1985:43-8.

12. Wang Q, Millward I. Developing a unified psychological model of coaching and mentoring in supporting the learning and development of adolescents. Int J Evid Based Coach Mentor 2014;12:91-108.

13. Sezer $\mathrm{H}$, Şahin $\mathrm{H}$, Uluer $\mathrm{H}$. The coaching process evaluation scale used in nursing education. New Trends Issues Proc Humanit Soc Sci 2017;4:51-7.

14. Twelker $P$. The critical incident technique: a manual for its planning and implementation. Illinois: Reflections at Twilight; 2003. http://www.tiu.edu/psychology/Twelker/critical_ incident_technique.htmlon [Accessed 12 Aug 2021].

15. American Association of Colleges of Nursing. Faculty shortages in baccalaureate and graduate nursing programs: scope of the problem and strategies for expanding the supply; 2005. http:// www.aacn.nche.edu/Publications/pdf/\%0A05FacShortage.pdf.

16. Hinshaw A. A continuing challenge: the shortage of educationally prepared nursing faculty. Online J Issues Nurs 2001;6:1-3.
17. Welp A, Johnson A, Nguyen H, Perry L. The importance of reflecting on practice: how personal professional development activities affect perceived teamwork and performance. J Clin Nurs 2018;1:12.

18. NMB (Nursing and Midwifery Board of Australia). Registration standard. Continuing Professional Development; 2016.

19. Chen C, Lou M. The effectiveness and application of mentorship programmes for recently registered nurses: a systematic review. I Nurs Manag 2014;22:433-42.

20. Plourde Cole F, Davis D, Davis N. Reconceptualizing continuing professional development to close long-standing quality gaps in palliative care. Am J Med Qual 2015;30: 389-394.

21. Tan K, Cashell A, Bolderston A. Encouraging reflection: do professional development workshops increase the skill level and useof reflection in practice? J Radiother Pract 2012;11: 135-44.

22. Boucher BA, Chyka PJ, Fitzgerald WL, Hak LJ, Miller DD, Parker RB, et al. A comprehensive approach to faculty development. Am J Pharmaceut Educ 2006;70:1-6.

23. Davis G, Foley B, Horn E, Neal E, Redman R, Van Riper M. Creating a comprehensive faculty development program. J Fac Dev 2003; 19:19-28.

24. Erklenz-Watts M, Westbay T, Lynd-Balta E. An alternative professional development program: lessons learned. Coll Teach 2006;54:275-9.

25. Glowacki-Dudka M, Brown M. Professional development through faculty learning communities. New Horiz 2007;21: 29-39.

26. Schmitz C, Luxenberg M. Evaluation of the "Learning by Doing" Faculty Development Program for the Minnesota State Colleges and Universities (MnSCU) Center for Teaching and Learning. Final report summary. St. Paul, MN: MnSCU and Bush Foundation; 2002.

27. Westcott L. How coaching can play a key role in the development of nurse managers. J Clin Nurs 2016;25:2669-77.

28. Baron L, Morin L. The impact of executive coaching on selfefficacy related to management soft-skills. Leader Organ Dev J 2010;31:18-38.

29. Broome ME, Bowersox D, Relf M. A new funding model for nursing education through business development initiatives. J Prof Nurs 2018;34:97-102.

30. Gentry W, Manning L, Wolf Kyle A, Broome Hernez G, Allen Whittier L. What coaches believe are best practices for coaching. J Leader Stud 2013;7:18-31.

31. Starck PL. The cost of doing business in nursing education. J Prof Nurs 2005;21:183-90.

32. Franzini L, Low M, Proll M. Using a cost-construction model to assess the cost of educating undergraduate medical students at the University of Texas-Houston Medical School. Acad Med 1997; 72:228-3.

33. Hemşirelik Eğitimi Derneği, HUÇEP. Hemşirelik Ulusal Çekirdek Eğitim Programı (HUÇEP). Ankara: HEMED; 2014. http://www. hemed.org.tr/2014-hucep/ [Accessed 12 Aug 2021].

34. World Health Organization. Human Resources for Health Global Standards for the Initial Education of Professional Nurses and Midwives; 2009. www.who.int/.../nursing_midwifery/hrh_ global_standards. 